\title{
KẾT QUẢ SỚM VÀ TRUNG HẠN PHÃU THUẠTT THAY VAN HAI LÁ ÍT XÂM LẤN CÓ NỘI SOI HỖ TRỢ QUA ĐƯỜnG NGỰC PHẢI TẠI BỆNH VIỆN BẠCH MAI
}

Phạm Quốc Đạt ${ }^{1 *}$, Dương Đức Hùng ${ }^{1}$, Nguyễn Hũu Uớc ${ }^{2}$

\section{TÓM TẮT}

Mục tiêu: Nghiên cứu nhằm đánh giá kết quả sớm và trung hạn phẫu thuật thay van hai lá ít xâm lấn có nội soi hỗ trợ tại Bệnh viện Bạch Mai.

Phương pháp nghiên cứu: Nghiên cứu mô tả tiến cứu gồm 106 bệnh nhân từ $1 / 2018$ đến $12 / 2020$ với thời gian theo dõi sau mổ ít nhất 6 tháng.

Kết quả: Tuổi trung bình là 50,5 $\pm 10,5$; nữ chiếm $64,2 \%$; NYHA III-IV trước mổ chiếm $50,0 \%$; phân suất tống máu thất trái (LVEF) dưới $50 \%$ chiếm $2,8 \%$; áp lực động mạch phổi (ALĐMP) trên $65 \mathrm{mmHg}$ chiếm 13,2\%. Cơ chế bệnh sinh do thấp tim, thoái hoá và viêm nội tâm mạc chiếm lần lượt là $75,5 \% ; 14,1 \%$; và $10,4 \%$. Thời gian chạy máy tuần hoàn ngoài cơ thể (THNCT) và cặp động mạch chủ (ĐMC) lần lượt là 95,1 phút và 63,2 phút. Yếu tố liên quan đến thời gian THNCT và cặp ĐMC là sửa van ba lá và khâu vắt van hai lá. Tỉ lệ tử vong sớm là $0,9 \%$, chuyển mở xương ức là $0,9 \%$. Thời gian thở máy, nằm hồi sức, nằm viện lần lượt là 16,8 giờ, 48,0 giờ, và 10,5 ngày. Các yếu tố ảnh hưởng đến khả năng xảy ra biến chứng nặng gồm: viêm nội tâm mạc, tăng ALĐMP nặng, hở van ba lá vừa/nặng và thiếu cân. Theo dõi trung hạn trên 105 bệnh nhân với thời gian trung bình là 17,9 tháng. Tỉ lệ tử vong trung hạn là $1,0 \%$, phẫu thuật lại là 3,8\%.

Kết luận: Phẫu thuật thay van hai lá ít xâm lấn qua đường mở ngực phải có nội soi hỗ trợ là phương pháp an toàn, cho kết quả ngắn hạn và trung hạn khả thi.

Tì khoá: İ́t xâm lấn, thay van hai lá.
EARLY AND MID-TERM RESULTS OF MINIMALLY INVASIVE VIDEO-ASSISTED MITRAL VALVE REPLACEMENT VIA RIGHT THORACOTOMY AT BACH MAI HOSPITAL

\section{ABTRACT}

Objective: The study aimed to evaluate the early and mid-term results of minimally invasive video-assisted mitral valve replacement surgery at Bach Mai Hospital.

Methods: A descriptive study. Including 106 patients from January 2018 to December 2020 with a follow-up period of at least six months.

Result: Mean age was $50.5 \pm 10.5$; Rate of female was $64.2 \%$; pre-operative NYHA III-IV class in $53(50.0 \%)$ cases; LVEF less than 50\% in 3 (2.8\%) cases; Pulmonary artery hypertension (over $65 \mathrm{mmHg}$ ) in $14(13.2 \%)$ cases. The pathogenesis of rheumatic heart disease, degeneration, and endocarditis accounted for $75.5 \%$, respectively; $14.1 \%$; and $10.4 \%$. The cardiopulmonary bypass time and the cross-clamp time is 95.1 minutes and 63.2 minutes, respectively. The factors related to the cardiopulmonary bypass time and the cross-clamp time were tricuspid valve repair and mitral valve replacement by continuous suture technique. Early mortality was $0.9 \%$, rate of conversion to sternotomy was $0.9 \%$. The mechanical ventilation time, length of ICU stay, and length of hospital

\footnotetext{
${ }^{1}$ Viện Tim mạch, Bệnh viện Bạch Mai

${ }^{2}$ Đại học Y Hà Nội.

*Tác giả liên hệ:Phạm Quốc Đạt;Email: dr.phamquocdat@gmail.com Ngày nhận bài: 18/08/2021 Ngày cho phép đăng: 30/09/2021
} 
stay were 16.8 hours, 48.0 hours, and 10.5 days, respectively. Factors that influence the severe complications include endocarditis, severe pulmonary hypertension, moderate/severe tricuspid regurgitation, and under-weight. Midterm follow-up was on 105 patients with a mean duration of 17.9 months. The mid-term mortality was $1.0 \%$, the re-operative rate was $3.8 \%$.

Conclusion: Minimally invasive videoassisted mitral valve replacement surgery through right thoracotomy is a safe method with possible short- and mid-term results.

Keywords: Minimally invasive, mitral valve replacement.

\section{ĐẠT V VẤN ĐỀ}

Bệnh lý van hai lá là bệnh van tim phổ biến ở nước ta. Phẫu thuật thay van hoặc sửa van giữ vai trò quan trọng trong điều trị bệnh van hai lá, nhất là khi bộ máy van đã tổn thương nặng nề. Phẫu thuật thay van hai lá qua đường mở xương ức truyền thống được thực hiện từ những năm 1960s và đã đạt được kết quả sau mổ rất tốt, nhất là với các tiến bộ về kỹ thuật bảo vệ cơ tim và những cải tiến của van nhân tạo. Tuy nhiên, hai xu thế mới đang dần trở thành những hướng đi chính thay thế cho thay van hai lá truyền thống là phẫu thuật ít xâm lấn và thay van hai lá qua đường ống thông.

Mặc dù, phẫu thuật van hai lá ít xâm lấn được triển khai sớm ở các nước phương Tây nhưng do đặc điểm bệnh lý van hai lá nên các nghiên cứu đã công bố chủ yếu về sửa van hai lá. Tại Việt Nam, phẫu thuật van hai lá ít xâm lấn có nội soi hỗ trợ đã được thực hiện từ năm 2013. Các kết quả ban đầu cho thấy đây là phương pháp an toàn và khả thi, tuy nhiên cho đến nay chưa có nghiên cứu nào công bố về kết quả trung hạn và dài hạn của thay van hai lá ít xâm lấn. Mặt khác, việc áp dụng phẫu thuật ít xâm lấn ở các trung tâm khác nhau có những đặc thù, cải tiến riêng, các kinh nghiệm này giúp cho việc phẫu thuật ít xâm lấn thuận tiện, an toàn và hiệu quả hơn. Đơn vị Phẫu thuật Tim mạch, Viện Tim mạch, Bệnh viện Bạch Mai với số ca mổ tim hở trung bình 1000 ca/năm, cũng là một trong các nơi triển khai khá sớm phẫu thuật tim ít xâm lấn. Chính vì các lý do trên, một nghiên cứu về thay van hai lá ít xâm lấn tại Bệnh viện Bạch Mai là thực sự cần thiết nhằm: Đánh giá kết quả sớm và trung hạn phẫu thuật thay van hai lá it xâm lấn có nội soi hỗ trợ qua đường ngục phải tại Bệnh viện Bạch Mai.

\section{PHƯƠNG PHÁP NGHIÊN CÚU}

Thiết kế nghiên cứu: Mô tả cắt ngang.

Đối tựng nghiên cúu: Gồm tất cả bệnh nhân phẫu thuật thay van hai lá bằng phương pháp ít xâm lấn qua đường ngực phải có nội soi hỗ trợ tại Bệnh viện Bạch Mai, được theo dõi sau mổ ít nhất 6 tháng, từ 1/2018 đến 12/2020.

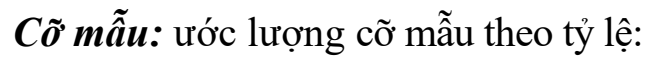

$$
n \geq Z_{1-\pi / 2} \frac{p(1-p)}{d^{2}}
$$

Trong đó: $\mathrm{Z}_{1-\alpha / 2}=1,96$ (chọn $\alpha=0,05$; độ tin cậy $95 \%$ ); $d=0,05$ (sai lệch mong muốn so với các nghiên cứu khác); $p$ là tỉ lệ ước tính dựa trên các nghiên cứu đã công bố. Tỉ lệ tử vong sớm, trung hạn theo Glauber (2015) trên 467 bệnh nhân thay van hai lá ít xâm lấn đường ngực phải là $3,2 \%$ và $7,2 \%$, thay vào công thức tính được cỡ mẫu tối thiểu là 102 bệnh nhân [1].

Quy trình kĩ thuật: Bệnh nhân được gây mê, đặt nội khí quản chọn lọc; tư thế nằm nghiêng trái $30-45^{\circ}$. Mở ngực vào khoang liên sườn IV qua đường mở ngực trước bên 4-6 cm. Đặt tờ-rôca cho ca-mê-ra nội soi vào khoang liên sườn III đường nách trước. Mở màng tim song song và cách thần kinh hoành ít nhất $3 \mathrm{~cm}$, khâu treo 
màng tim ra thành ngực bộc lộ tim. Thiết lập tuần hoàn ngoài cơ thể ngoại vi qua bó mạch đùi và tĩnh mạch cảnh trong phải nếu có chỉ định. Cặp động mạch chủ qua thành ngực bằng cờ-lăm Chitwood tại khoang liên sườn $\mathrm{IV}$, đường nách giữa. Liệt tim bằng dung dịch liệt tim máu ấm xuôi dòng qua gốc động mạch chủ. Bộc lộ van hai lá bằng dụng cụ vén nhĩ qua đường mở thành bên nhĩ trái. Thay van hai lá bằng kĩ thuật khâu vắt hoặc khâu mũi rời. Xử lí thương tổn kèm theo gồm khâu tiểu nhĩ, sửa van ba lá, khâu thông liên nhĩ nếu có. Kết thúc ca mổ, đóng các đường mở tim, thả cặp động mạch chủ. Cai máy tuần hoàn ngoài cơ thể. Rút các ống thông tĩnh mạch và động mạch, khâu phục hồi động mạch, tĩnh mạch đùi. Đặt dẫn lưu, kiểm tra cầm máu trước khi đóng vết mổ.

X $\vec{u}$ lý số liệu: Số liệu xử lý bằng phần mềm SPSS 18.0. Do tỉ lệ tử vong sau mổ thấp nên biến cố gộp là biến chứng nặng được sử dụng làm biến kết cục để phân tích tìm các yếu tố liên quan đến kết quả phẫu thuật. Trong đó:

Biến chứng nặng được định nghĩa khi có ít nhất 1 biến chứng gồm: tư vong, nhồi máu co tim, tai biến mạch não, suy thận mới, mổ lại, chuyển mở xuong úc, thở máy kéo dài trên 48 giờ, họi chưng cung luợng tim thấp kéo dài [2].
Hội chứng cung lựng tim thấp (Low Cardiac Output Syndrome - LCOS) được định nghĩa là bệnh nhân phải dùng biện pháp hô trợ tuần hoàn co hoc (bóng đối xung động mạch chủ (IABP) hoặc ECMO) hoặc phải dùng các thuốc vận mạch nhằm duy trì huyết áp tâm thu trên 90 mmHg (hoặc cung luọng tim > 2,2 L/phút $/ \mathrm{m}^{2} \mathrm{co}$ ' thể) trong vòng it nhất 30 phút tại phòng hồi súc sau khi đã điều chỉnh cân bằng điện giải, khí máu và đảm bảo đủ tiền gánh và giảm hậu gánh [3].

Đạo đúc nghiên cúu: Đề tài được thông qua hội đồng đạo đức theo quyết định số $02 \mathrm{NCS} 17$ của trường Đại học $\mathrm{Y}$ Hà Nội và hội đồng đạo đức, Bệnh viện Bạch Mai.

\section{KẾT QUẢ NGHIÊN CÚU}

Trong thời gian 1/2018-12/2020 có 106 bệnh nhân phẫu thuật thay van hai lá ít xâm lấn qua đường ngực phải có nội soi hỗ trợ đưa vào nghiên cứu. Tuổi trung bình là 50,5 với nhóm tuổi trên 60 chiếm 16,0\%. Phân loại bệnh nhân theo BMI có 21 bệnh nhân thiếu cân $(\mathrm{BMI}<$ $18,5)$ chiếm $19,8 \%$; 8 bệnh nhân thừa cân (BMI: 25-29,9) chiếm 7,6\%. Đặc điểm trước mổ được trình bày tại (bảng 1 ).

\section{Bảng 1. Đặc điểm trước mổ}

\begin{tabular}{|l|r|}
\hline Đặc điểm trước mổ (n=106) & Giá trị \\
\hline Tuồi trung bình & $50,5 \pm 10,5$ \\
\hline Giới nữ & $68(64,2 \%)$ \\
\hline Chỉ số khối cơ thể (BMI) & $20,9 \pm 2,7$ \\
\hline EuroScore > 2\% & $18(17,9 \%)$ \\
\hline NYHA III-IV & $53(50,0 \%)$ \\
\hline Tiền sử & $59(55,7 \%)$ \\
\hline Rung nhĩ & $10(9,4 \%)$ \\
\hline Đái tháo đường & $16(15,1 \%)$ \\
\hline Tăng huyết áp & \multicolumn{1}{|c|}{} \\
\hline
\end{tabular}




\begin{tabular}{|l|r|}
\hline COPD & $4(3,8 \%)$ \\
\hline Tai biến mạch não & $13(12,3 \%)$ \\
\hline Suy thận trước mổ & $14(13,2 \%)$ \\
\hline Bệnh mạch máu ngoại vi & $1(0,9 \%)$ \\
\hline Nong van cũ & $20(18,9 \%)$ \\
\hline Tách van cũ & $1(0,9 \%)$ \\
\hline Siêu âm tim & $3(2,8 \%)$ \\
\hline LVEF $<50 \%$ & $14(13,2 \%)$ \\
\hline ALĐMP $\geq 65$ mmHg & $17(16,0 \%)$ \\
\hline Hở van ba lá nặng & \\
\hline Cơ chế bệnh sinh & $80(75,5 \%)$ \\
\hline Thấp tim & $15(14,1 \%)$ \\
\hline Thoái hoá & $11(10,4 \%)$ \\
\hline Viêm nội tâm mạc & \\
\hline
\end{tabular}

Bảng 2. Đặc điểm trong mổ

\begin{tabular}{|l|c|c|}
\hline \multicolumn{2}{|c|}{ Đặc điểm trong mổ (n=106) } & Giá trị \\
\hline + Kĩ thuật thay van hai lá & Có & $104(98,1 \%)$ \\
\hline \multirow{2}{*}{ Bảo tồn lá sau } & Không & $2(1,9 \%)$ \\
\hline \multirow{2}{*}{ Loại van } & Cơ học & $71(67,0 \%)$ \\
\cline { 2 - 3 } & Sinh học & $35(33,0 \%)$ \\
\hline \multirow{2}{*}{ Kĩ thuật khâu van } & Mũi vắt & $69(65,1 \%)$ \\
\cline { 2 - 3 } & Mũi rời & $37(34,9 \%)$ \\
\hline \multirow{3}{*}{ Kích thước van } & 27 & $44(41,5 \%)$ \\
\cline { 2 - 3 } & 29 & $41(38,7 \%)$ \\
\cline { 2 - 3 } & 31 & $17(16,0 \%)$ \\
\hline + Xử lý thương tổn kèm theo & 33 & $25(3,8 \%)$ \\
\hline Sửa van ba lá & $23(21,7 \%)$ \\
\hline Khâu tiểu nhĩ trái & $2(1,9 \%)$ \\
\hline Khâu thông liên nhĩ & $95,1 \pm 19,1$ \\
\hline + Thời gian THNCT và cặp ĐMC (phút) & $63,2 \pm 16,0$ \\
\hline Tuần hoàn ngoài cơ thể & \multicolumn{2}{|l}{} \\
\hline Cặp động mạch chủ &
\end{tabular}

Đặc điểm trong mổ của các bệnh nhân được trình bày tại (bảng 2). Có 71 bệnh nhân thay van cơ học, trong đó có 69 bệnh nhân thay van bằng kĩ thuật khâu vắt; 2 bệnh nhân bằng khâu mũi rời do vòng van quá yếu trên bệnh nhân viêm nội tâm mạc. Tất cả van sinh học đều được khâu van bằng kĩ thuật khâu mũi rời. 
Bảng 3. Yếu tố kĩ thuật ảnh hưởng đến thời gian cặp chủ và tuần hoàn ngoài cơ thể

\begin{tabular}{|l|r|r|r|}
\hline \multicolumn{1}{|c|}{ Yếu tố } & B & $\mathbf{9 5 \%}$ CI & \multicolumn{1}{|c|}{ p } \\
\hline Ánh hướng thời gian cặp chủ (phút) $\left(R^{2}=0,239\right)$ & \multicolumn{3}{|c|}{} \\
\hline Sửa van ba lá & 11,5 & $5,0 \div 17,9$ & $<0,001$ \\
\hline Khâu vắt VHL & $-11,7$ & $-17,5 \div-5,9$ & $<0,001$ \\
\hline Ánh hướng thời gian chạy máy (phút) $\left(R^{2}=0,203\right)$ \\
\hline Sửa van ba lá & 12,4 & $4,5 \div 20,2$ & 0,002 \\
\hline Khâu vắt VHL & $-13,0$ & $-20,0 \div-6,0$ & \\
\hline
\end{tabular}

Kết quả phân tích hồi quy tuyến tính đa biến các yếu tố ảnh hưởng đến thời gian cặp chủ gồm sửa van ba lá có nguy cơ làm tăng 11,5 phút cặp chủ; khâu vắt van hai lá có thể tiết kiệm 11,7 phút cặp chủ. Yếu tố ảnh hưởng đến thời gian THNCT gồm sửa van ba lá có nguy cơ làm tăng 12,4 phút, khâu vắt van tiết kiệm được 13,0 phút thời gian THNCT (bảng 3).

Bảng 4. Đặc điểm kết quả sớm

\begin{tabular}{|l|c|}
\hline \multicolumn{1}{|c|}{ Kết quả sớm (n=106) } & Giá trị \\
\hline + Biến chứng nặng & $\mathbf{2 8}(\mathbf{2 6 , 4 \% )}$ \\
\hline Tử vong sớm & $1(0,9 \%)$ \\
\hline Chuyển mở xương ức & $1(0,9 \%)$ \\
\hline LCOS > 48 giờ & $24(22,6 \%)$ \\
\hline IABP hoặc ECMO & $2(1,9 \%)$ \\
\hline Suy thận mới sau mổ & $5(4,7 \%)$ \\
\hline Thở máy > 48 giờ & $5(4,7 \%)$ \\
\hline Mổ lại lý do bất kì & $4(3,7 \%)$ \\
\hline Nhồi máu cơ tim & $1(0,9 \%)$ \\
\hline + Biến chứng nhẹ khác & \\
\hline Loạn thần/Động kinh & $3(2,8 \%)$ \\
\hline Tràn dịch màng tim & $1(0,9 \%)$ \\
\hline Tràn dịch/ khí màng phổi & $7(6,6 \%)$ \\
\hline Viêm phổi sau mổ & $4(3,7 \%)$ \\
\hline Nhiễm trùng huyết & $1(0,9 \%)$ \\
\hline Nhiễm trùng vết mổ ngực & $1(0,9 \%)$ \\
\hline Rò dưỡng chấp vết mổ đùi & $2(1,9 \%)$ \\
\hline Tổn thương thần kinh đùi & $4(3,7 \%)$ \\
\hline + Thời gian thở máy (giờ) & $16,8 \pm 26,9$ \\
\hline + Thời gian hồi sức (giờ) & $48,0 \pm 32,2$ \\
\hline + Thời gian nằm viện (ngày) & $10,5 \pm 5,4$ \\
\hline
\end{tabular}


Kết quả sớm được trình bày trong bảng 4 . Tỉ lệ gặp ít nhất một biến chứng nặng là 26,4\%; trong đó chủ yếu là hội chứng cung lượng tim thấp kéo dài trên 48 giờ, tuy nhiên chỉ có 2 bệnh nhân phải hỗ trợ tuần hoàn bằng biện pháp cơ học (1 bệnh nhân đặt IABP, 1 bệnh nhân đặt ECMO). Trong đó bệnh nhân đặt ECMO tử vong do suy tim không hồi phục. Có một trường hợp phải chuyển mở xương ức do nguyên nhân chảy máu từ tiểu nhĩ trái. Có 4 bệnh nhân phải mổ lại, nguyên nhân do hở van ba lá sau mổ (1 bệnh nhân); vỡ thất trái sau mổ (1 bệnh nhân); máu cục màng phổi (2 bệnh nhân).

Bảng 5. Yếu tố ảnh hưởng đến nguy cơ xảy ra biến chứng nặng

\begin{tabular}{|l|c|c|c|}
\hline \multicolumn{1}{|c|}{ Yếu tố } & OR & $\mathbf{9 5 \%}$ CI & $\boldsymbol{p}$ \\
\hline Viêm nội tâm mạc & 9,85 & $1,14 \div 7,68$ & 0,026 \\
\hline TALĐMP nặng & 3,98 & $1,01 \div 15,7$ & 0,049 \\
\hline Hở ba lá vừa/nặng & 4,00 & $1,40 \div 11,5$ & 0,010 \\
\hline Thiếu cân & 3,14 & $1,01 \div 9,72$ & 0,047 \\
\hline
\end{tabular}

Kết quả phân tích hồi quy đa biến logistic các yếu tố dự báo nguy cơ xảy ra biến chứng nặng có ý nghĩa thống kê gồm viêm nội tâm mạc nhiễm khuẩn (OR: 9,85); tăng áp lực động mạch phổi nặng (OR: 3,98); hở ba lá vùa hoặc nặng (OR: 4,00) và yếu tố thiếu cân (OR: 3,14) (bảng 5).

Bảng 6. Tỉ lệ các biến cố theo dõi trung hạn

\begin{tabular}{|l|c|}
\multicolumn{1}{|c|}{$\quad$ Biến cố $(\mathbf{n = 1 0 5})$} & Giá trị \\
\hline Tử vong trung hạn & $1(1,0 \%)$ \\
\hline Phẫu thuật lại & $4(3,8 \%)$ \\
\hline + Liên quan đến van hai lá & $3(2,8 \%)$ \\
\hline + Liên quan đến nguyên nhân khác & $1(1,0 \%)$ \\
\hline Tai biến mạch não & \\
\hline
\end{tabular}

Ngoài 1 bệnh nhân tử vong tại viện, 105 bệnh nhân ra viện đều được theo dõi và khám định kỳ. Thời gian theo dõi trung bình là 17,9 tháng, ngắn nhất 6 tháng, dài nhất 34 tháng. Tỉ lệ tử vong trung hạn là $1,0 \%$. Có 4 bệnh nhân phải phẫu thuật lại, trong đó có 3 bệnh nhân liên quan đến van hai lá, và 1 bệnh nhân do nguyên nhân hẹp động mạch đùi (bảng 6).

Theo dõi các biến chứng vết mổ đùi, có 1 bệnh nhân hẹp khít động mạch đùi, phải tạo hình lại động mạch đùi. Trong 4 bệnh nhân tổn thương thần kinh đùi, có 3 bệnh nhân hồi phục hoàn toàn sau 6 tháng, 1 bệnh nhân còn tê bì nhẹ.

Triệu chứng lâm sàng cải thiện theo thời gian với tỉ lệ bệnh nhân NYHA I tăng dần tại các thời điểm khám lại (biểu đồ 1). 


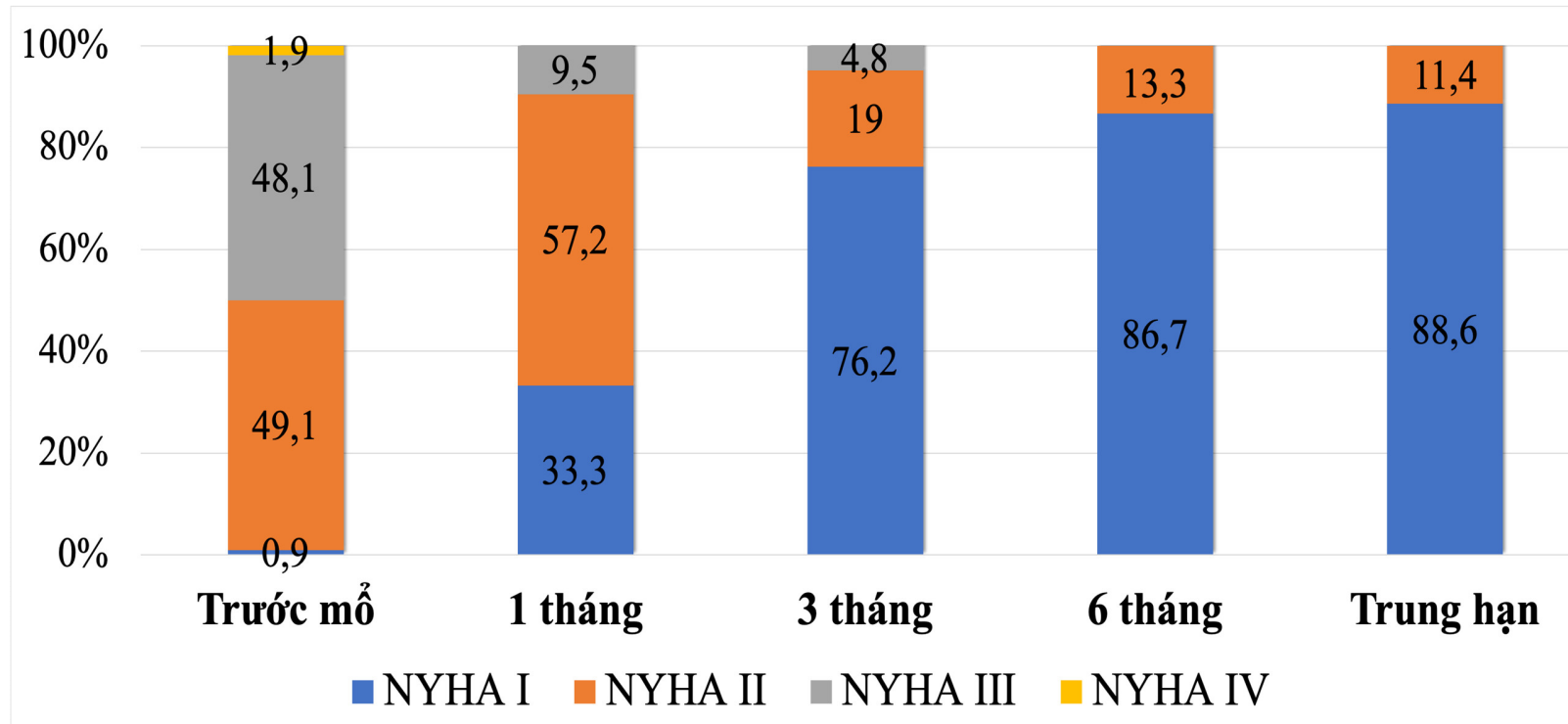

Biểu đồ 1. Thay đổi tỉ lệ NYHA qua các giai đọ̣n

\section{BÀN LUẬN}

Trong quy trình thay van hai lá ít xâm lấn đường ngực phải, chúng tôi lựa chọn phương pháp thông khí chọn lọc bằng nội khí quản hai nòng. Uu điểm của phương pháp này là dễ dàng tiếp cận tim trước khi chạy máy và sau khi ngừng máy tuần hoàn ngoài cơ thể, do đó tiết kiệm được thời gian chạy máy THNCT hơn so với phương pháp không sử dụng thông khí chọn lọc. Trong thiết lập tuần hoàn ngoài cơ thể, chúng tôi thiết lập tuần hoàn ngoài cơ thể ngoại vi qua bó mạch đùi và tĩnh mạch cảnh trong phải trong trường hợp cần can thiệp vào tim phải. Uu điểm của phương pháp là giải phóng được phẫu trường ngực. Nhược điểm của phương pháp này theo các nghiên cứu trên thế giới là có thể gây lóc động mạch chủ ngược dòng hoặc tai biến mạch não do huyết khối hoặc mảnh xơ vữa di chuyển [4]. Tuy nhiên, chúng tôi không gặp trường hợp nào bị lóc động mạch chủ ngược dòng hay tai biến mạch não. Kinh nghiệm của chúng tôi trong thiết lập ống thông động mạch là chỉ cần sử dụng ống thông cỡ $18 \mathrm{Fr}$ hoặc $20 \mathrm{Fr}$ là đủ đáp ứng lưu lượng bơm mà vẫn đảm bảo an toàn cho các bệnh nhân; với ống thông tĩnh mạch sử dụng cỡ $23 \mathrm{Fr}$ hoặc 25Fr loại đa tầng kèm theo hút áp lực âm trong chạy máy là đủ đảm bảo lưu lượng tĩnh mạch mà vẫn phù hợp với kích thước người Việt Nam. Với các biến chứng tại vết mổ đùi, chúng tôi gặp 2 trường hợp bị rò dưỡng chấp, 4 trường hợp tổn thương thần kinh đùi dẫn đến hiện tượng tê bì mặt trong đùi tạm thời sau mổ, và 1 trường hợp hẹp động mạch đùi muộn sau mổ 1,5 tháng. Kinh nghiệm của chúng tôi rút ra là cần hết sức cẩn thận khi phẫu tích động mạch và tĩnh mạch đùi, tránh tổn thương các hạch bạch huyết, tránh sử dụng dao điện cường độ quá cao hoặc phẫu tích ra phía ngoài nhiều vì có thể gây tổn thương thần kinh đùi; với trường hợp động mạch đùi quá bé thì nên đặt ống thông gián tiếp qua một mạch nhân tạo số 8 , tránh đặt ống thông quá to gây tổn thương vi thể lớp nội mạc dẫn đến xơ hoá và hẹp động mạch muộn sau mổ. Mặt khác, cần theo dõi cẩn thận các biến chứng về thần kinh, mạch máu và bạch huyết đùi sau phẫu thuật để phát hiện và xử lí kịp thời. Một xu hướng khác trong phẫu 
thuật ít xâm lấn là sử dụng các dung dịch liệt tim có thời gian bảo vệ cơ tim dài như (CustodiolHTK hay Del Nido) nhưng trong nghiên cứu của chúng tôi vẫn sử dụng máu ấm để bảo vệ cơ tim vì lý do thay van thời gian thường không mất quá nhiều thời gian và máu ấm được chứng minh bảo vệ cơ tim tốt. Trên thực tế, chúng tôi không gặp phải khó khăn gì khi sử dụng phương pháp trên.

Một trong những cải tiến trong kĩ thuật thay van của chúng tôi là sử dụng kĩ thuật khâu vắt cho 69/71 bệnh nhân thay van hai lá cơ học; chỉ có 2 bệnh nhân chúng tôi sử dụng kĩ thuật khâu mũi rời cho van hai lá cơ học vì vòng van yếu trên bệnh nhân viêm nội tâm mạc nhiễm khuẩn. Chúng tôi chỉ định khâu vắt cho các trường hợp thay van hai lá cơ học với vòng van không quá bé, không quá mỏng hay vôi hóa; chỉ định khâu mũi rời cho thay van sinh học hoặc trường hợp vòng van vôi hoá, mỏng hay quá bé. Các kĩ thuật khâu vắt trong thay van hai lá ban đầu được giới thiệu với mục tiêu giảm thời gian chạy máy và thời gian cặp động mạch chủ. Mặt khác, buộc chỉ trong phẫu thuật tim ít xâm lấn thường khó và mất nhiều thời gian hơn vì phẫu thuật viên phải thực hiện trong một phẫu trường hẹp và sâu. Chúng tôi sử dụng kỹ thuật khâu vắt nhằm giảm thiểu thời gian buộc chỉ lặp đi lặp lại của kĩ thuật khâu mũi rời. Trong nghiên cứu của chúng tôi, khâu vắt là yếu tố giúp giảm thời gian cặp chủ và chạy máy tuần hoàn ngoài cơ thể có ý nghĩa thống kê. Trong nghiên cứu, các bệnh nhân bệnh van hai lá do thấp chiếm phần lớn với đặc điểm vòng van dày và chắc chắn, phù hợp cho việc thực hiện kĩ thuật khâu vắt với kết quả an toàn và không gặp biến cố nào liên quan đến van nhân tạo.

Chúng tôi chỉ định sửa van ba lá cho các trường hợp có hở van ba lá nặng và hở van ba lá vừa mà có tăng áp lực động mạch phổi. Tỉ lệ sửa van ba lá kèm theo là 23,6\%. Khi phân tích đơn biến, đa biến thì sửa van ba lá là yếu tố làm tăng thời gian cặp chủ, chạy máy lên lần lượt là 11,5 phút và 12,4 phút có ý nghĩa thống kê. Tuy nhiên, tỉ lệ tử vong chung của nhóm bệnh nhân trong nghiên cứu là không cao. Do vậy, phẫu thuật van ba lá kèm theo không phải là chống chỉ định cho phẫu thuật van hai lá ít xâm lấn nhưng là một yếu tố cân nhắc khi chỉ định, đặc biệt đối với trung tâm mới triển khai phẫu thuật tim ít xâm lấn.

Thời gian cặp động mạch chủ và thời gian chạy tuần hoàn ngoài cơ thể là các yếu tố được quan tâm hàng đầu trong đánh giá hiệu quả của phẫu thuật van hai lá ít xâm lấn. Cao và cộng sự trong nghiên cứu gộp so sánh giữa phẫu thuật van hai lá ít xâm lấn qua đường ngực phải với mở đường dọc giữa xương ức cho thấy một trong những nhược điểm của tiếp cận ít xâm lấn là kéo dài thời gian cặp động mạch chủ và thời gian chạy máy tuần hoàn ngoài cơ thể, sự khác biệt là có ý nghĩa thống kê [5].

Bảng 7. Thời gian THNCT và cặp ĐMC một số nghiên cứu van hai lá ít xâm lấn

\begin{tabular}{|l|c|c|}
\hline \multirow{2}{*}{ Nghiên cứu } & \multicolumn{2}{|c|}{ Thời gian (phút) } \\
\cline { 2 - 3 } & THNCT & Cặp ĐMC \\
\hline Glauber[1] & 131 & 88 \\
\hline Võ Tuấn Anh[6] & 155 & 103 \\
\hline P.Thành Đạt[7] & 157 & 113 \\
\hline Chúng tôi & 95,1 & 63,2 \\
\hline
\end{tabular}


Khi so sánh với các tác giả khác, thời gian cặp chủ và thời gian tuần hoàn ngoài cơ thể của chúng tôi ngắn hơn. Sự khác biệt này có thể do nhóm bệnh nhân của chúng tôi lấy sau khi các phẫu thuật viên đã vượt qua đường cong huấn luyện nên thời gian phẫu thuật đã cải thiện. Trong kĩ thuật xử lí thương tổn van hai lá, các bệnh nhân đều được chỉ định thay van ngay từ đầu và sử dụng kĩ thuật khâu vắt cũng giúp tiết kiệm thời gian hơn so với kĩ thuật khâu van mũi rời.

Nguyên nhân thất bại chuyển mở xương ức, theo số liệu của trung tâm Leipzig trong 15 năm, có 3125 bệnh nhân được phẫu thuật van hai lá ít xâm lấn, trong đó có 34 bệnh nhân phải chuyển mổ mở xương ức (1\%). Nguyên nhân chính là do chảy máu (tổn thương tiểu nhĩ trái, mỏm thất trái, động mạch chủ lên), phổi rất dính và lóc động mạch chủ type $\mathrm{A}$. Tỉ lệ tử vong trong 30 ngày của các bệnh nhân chuyển mở xương ức là khá cao, lên đến $23,5 \%$ [8]. Trong nghiên cứu của chúng tôi có 1 bệnh nhân phải chuyển mổ mở xương ức, nguyên nhân do chảy máu từ tiểu nhĩ trái. Chảy máu từ tiểu nhĩ trái do cặp động mạch chủ từ thành ngực gây nên là tổn thương kinh điển đã được biết đến trong phẫu thuật van hai lá ít xâm lấn. Do vậy, các tác giả cũng đưa ra khuyến cáo cần quan sát rõ tiểu nhĩ trái qua xoang ngang của tim với hỗ trợ của nội soi khi đặt cặp động mạch chủ để tránh tổn thương tiểu nhĩ trái. Tóm lại, chuyển mở xương ức trong quá trình phẫu thuật ít xâm lấn đường ngực phải là một biến chứng ít gặp nhưng nặng, nguy cơ dẫn đến tử vong cao. Để hạn chế biến chứng này thì cần chỉ định và lựa chọn bệnh nhân phù hợp, tuân thủ các bước trong quy trình kĩ thuật nhằm hạn chế thấp nhất các rủi ro [8].

Kết quả sớm sau mổ, chúng tôi có 1 trường hợp tử vong sớm do suy tim sau mổ không hồi phục chiếm $0,9 \%$. Tỉ lệ tử vong sau mổ đối với phẫu thuật van hai lá ít xâm lấn qua đường ngực phải nói chung (gồm cả thay van và sửa van) khoảng $0,2 \%$ đến $3,7 \%$.[9, 10] Tuy nhiên, tỉ lệ tử vong do thay van hai lá ít xâm lấn qua đường mở ngực phải thường cao hơn so với sửa van. Tỉ lệ tử vong trên bệnh nhân sửa van hai lá ít xâm lấn dao động từ $0 \%$ đến $2,1 \%$, nhưng tỉ lệ tử vong do thay van hai lá ít xâm lấn cao hơn, dao động từ $0,9 \%$ đến $5,8 \%$ [6, 11-13]. Lý do tỉ lệ tử vong sau mổ sửa van hai lá thường thấp hơn so với thay van hai lá vì sửa van bảo tồn chức năng thất trái sau mổ tốt hơn so với thay van hai lá. Một số nghiên cứu của các tác giả Zhai, Liu và Chernov thực hiện ở Trung Quốc và Nga là nơi có mặt bệnh van hai lá tương tự như Việt Nam, so sánh kết quả phẫu thuật thay van hai lá ít xâm lấn đường ngực phải với đường mở xương ức, cho thấy tỉ lệ tử vong giữa hai phương pháp là tương đương, không có sự khác biệt có ý nghĩa thống kê.[12, 14, 15] Nguyên nhân tử vong chủ yếu được báo cáo trong các nghiên cứu gồm tai biến vỡ thất trái, hội chứng cung lượng tim thấp sau mổ, nhiễm trùng [12-15]. Đây cũng là những biến chứng kinh điển của phẫu thuật van hai lá nói chung, kể cả đường mở dọc giữa xương ức hay đường mở ít xâm lấn. Morh và cộng sự báo cáo trong nhóm bệnh nhân của mình có 1 ca vỡ thất; báo cáo của Zhai có 2 ca, đều là nguyên nhân dẫn đến tử vong sau mổ $[14,16]$. Vỡ thất trái là một trong những biến chứng nặng, rất khó xử trí và có tỉ lệ tử vong cao. Trong nghiên cứu của chúng tôi có một trường hợp bị biến chứng vỡ thất trái tại hồi sức nhưng được mổ lại kịp thời. Bệnh nhân sau mổ có hội chứng cung lượng tim thấp nặng nhưng sau đó hồi phục ra được viện. Trong nghiên cứu của chúng tôi, các yếu tố dự báo nguy cơ xảy ra biến chứng nặng có ý nghĩa thống kê gồm viêm nội tâm mạc nhiễm khuẩn (OR: 9,85); tăng áp lực động mạch phổi nặng (OR: 3,98); hở 
ba lá vừa hoặc nặng (OR: 4,00) và yếu tố thiếu cân (OR: 3,14). Tuy nhiên, các yếu tố này đều được coi là các yếu tố tiên lượng nặng với cả phẫu thuật van hai lá đường xương ức. Do vậy, chúng tôi cũng không coi đây là chống chỉ định của phẫu thuật van hai lá ít xâm lấn mà chỉ đưa ra khuyến cáo lựa chọn bệnh nhân cho các trung tâm mới thực hiện phẫu thuật ít xâm lấn.

Biến chứng thần kinh là một trong những vấn đề quan trọng được quan tâm trong phẫu thuật van hai lá ít xâm lấn. Trong giai đoạn đầu triển khai phẫu thuật ít xâm lấn, Morh và cộng sự thông báo tỉ lệ tai biến thần kinh lên đến $18 \%$. Tuy nhiên, sau khi rút kinh nghiệm và hoàn thiện các bước kĩ thuật, tỉ lệ này chỉ còn 3,1\% sau 10 năm [16]. Các giả thiết chính về nguyên nhân tai biến mạch não được các tác giả đưa ra bao gồm hạn chế đuổi khí do vết mổ nhỏ, phẫu trường hạn chế, sử dụng cặp động mạch chủ bằng bóng nội mạch và tưới máu ngược dòng. Tỉ lệ tai biến thần kinh ở các nghiên cứu phẫu thuật thay van hai lá ít xâm lấn với số lượng bệnh nhân lớn trên thế giới dao động từ $1,0 \%$ đến $5,1 \%$.[1, 11, 12, 15] Theo nghiên cứu của Phạm Thành Đạt tại trung tâm tim mạch Bệnh viện $\mathrm{E}$, tỉ lệ loạn thần sau mổ là 24,5\% nhưng không có bệnh nhân nào để lại di chứng; nghiên cứu của Võ Tuấn Anh tại Bệnh viện Y Dược thành phố Hồ Chí Minh có 1 bệnh nhân tai biến mạch não chiếm $0,5 \%$ [6, 17]. Trong nghiên cứu của chúng tôi, tỉ lệ có rối loạn thần kinh là 2,8\% (3/106 bệnh nhân), trong đó có 2 bệnh nhân biểu hiện kích thích sau hội chứng cung lượng tim thấp và 1 bệnh nhân lên cơn động kinh trên bệnh nhân có tiền sử động kinh cũ. Không có bệnh nhân nào có tai biến mạch não thực sự. Để hạn chế biến chứng thần kinh, chúng tôi dựa vào khám lâm sàng bệnh mạch máu và chỉ định siêu âm Doppler mạch máu trước mổ cho các bệnh nhân từ 50 tuổi trở lên, trên bệnh nhân có triệu chứng lâm sàng hoặc có yếu tố nguy cơ cao. Ngoài ra, chúng tôi chủ động đuổi khí kĩ qua dẫn lưu tim trái và gốc động mạch chủ trước khi thả cặp động mạch chủ. Hút gốc động mạch chủ liên tục được duy trì trong quá trình chạy máy hỗ trợ cho đến khi tim đập tốt.

Tỉ lệ mổ lại do chảy máu của các nghiên cứu về thay van hai lá ít xâm lấn trong khoảng từ $2,0 \%$ đến $6,4 \%[1,6,12,14,15,17]$. Trong đó, các nghiên cứu của Liu, Chernov và Zhai cho thấy tỉ lệ mổ lại do chảy máu không có sự khác biệt có ý nghĩa thống kê $[12,14,15]$. Trong nghiên cứu của chúng tôi, có 3 bệnh nhân phải mổ lại do chảy máu chiếm tỉ lệ $2,8 \%$, trong đó có 1 bệnh nhân mổ lại tối cấp cứu đường giữa xương ức do vỡ thất trái tại phòng hồi sức, 2 bệnh nhân mổ lại do máu cục màng phổi, được lấy máu cục qua đường mở ngực cũ. Tương tự như nghiên cứu của Võ Tuấn Anh và Phạm Thành Đạt, nguyên nhân chảy máu chủ yếu là từ vết mở ngực và lỗ chọc tờ-rô-ca $[6,17]$. Kinh nghiệm của chúng tôi rút ra nhằm giảm tỉ lệ chảy máu phải mổ lại là khi mở ngực tránh làm tổn thương màng xương của xương sườn, dùng dụng cụ vén phần mềm và không banh xương sườn quá rộng có thể gãy xương sườn gây chảy máu; cầm máu kĩ các lỗ trên thành ngực, chỗ chọc của kim gốc động mạch chủ và đường khâu nhĩ trái dưới hỗ trợ của ca-mê-ra nội soi sau khi trung hoà protamin và cầm máu kĩ mép vết mở ngực trước khi đóng ngực.

Trong nghiên cứu của chúng tôi, có 1 trường hợp tử vong trung hạn, chiếm tỉ lệ $1,0 \%$. Nguyên nhân tử vong của bệnh nhân không được biết rõ do bệnh nhân đột tử tại nhà. Tỉ lệ tử vong theo dõi trung hạn của chúng tôi thấp tương đương với các nghiên cứu về thay van hai lá tại thời điểm hiện tại trên thế giới. Tuy nhiên, thời gian theo dõi trung bình của chúng tôi là 17,9 tháng còn thấp so với các nghiên cứu trên thế 
giới. Vì vậy, cần theo dõi lâu dài hơn để đạt các mốc 5 năm, 10 năm để từ đó đánh giá kết quả dài hạn của phẫu thuật thay van hai lá ít xâm lấn.Tỉ lệ phải phẫu thuật lại của chúng tôi là 3,8\% trong thời gian theo dõi trung hạn. Trong đó có 1 bệnh nhân bị hẹp động mạch đùi chung tổn thương lớp nội mạc mạch máu tại vị trí thiết lập tuần hoàn ngoài cơ thể phải phẫu thuật tạo hình lại động mạch đùi sau 1,5 tháng. Có 3 bệnh nhân phẫu thuật lại liên quan đến van hai lá chiếm 2,9\%, trong đó có 1 bệnh nhân giả phình thất trái trên bệnh nhân tiền sử mổ vỡ thất trái sau mổ thay van hai lá, 1 bệnh nhân bị kẹt van hai lá cơ học, 1 bệnh nhân bị huyết khối van hai lá sinh học. Theo nghiên cứu của Võ Tuấn Anh, tỉ lệ phẫu thuật lại chung của phẫu thuật van hai lá ít xâm lấn là $1,5 \%$, trong đó thay van là $0,9 \%$ và sửa van là 2,2\% [6]. Tỉ lệ phẫu thuật lại sau 1 năm theo nghiên cứu của Glauber là $9 \%$ [1]. So sánh kết quả trung hạn và dài hạn của phẫu thuật thay van hai lá qua đường mở ngực ít xâm lấn và đường mở xương ức: các nghiên cứu đều cho thấy không có sự khác biệt có ý nghĩa thống kê về tỉ lệ tử vong cũng như mổ lại giữa hai phương pháp [14, 15]. So sánh kết quả trung hạn, dài hạn giữa phẫu thuật thay van và sửa van hai lá ít xâm lấn: theo nghiên cứu của Glauber, tỉ lệ sống còn sau thay van hai lá ít xâm lấn đường ngực phải tại thời điểm $1,5,10$ năm lần lượt là $91,0 \%, 81,3 \%$, và $76,2 \%$; tỉ lệ không phải mổ lại tại thời điểm 1 năm, 5 năm, 10 năm lần lượt là $92,7 \% ; 84,4 \%$ và $79,3 \%$ [1]. Tương tự như phẫu thuật van hai lá đường xương ức truyền thống, sửa van hai lá vẫn cho kết quả tốt hơn khi theo dõi dài hạn cả về tỉ lệ sống còn và tỉ lệ phải mổ lại.

Triệu chứng lâm sàng trước mổ đa số các bệnh nhân có suy tim NYHA II và NYHA III, tại các thời điểm khám lại sau 1 tháng, 3 tháng, 6 tháng và trung hạn tỉ lệ NYHA I tăng từ 33,3\% lên $88,6 \%$. Tại thời điểm khám lại lần cuối chỉ còn $11,4 \%$ bệnh nhân còn triệu chứng NYHA II, không có bệnh nhân nào có triệu chứng NYHA III và IV. Đa số các bệnh nhân cải thiện triệu chứng rõ ràng tại thời điểm sau mổ 6 tháng (NYHA I chiếm 86,7\%; còn lại là NYHA II chiếm 13,3\%). Kết quả này phù hợp với các nghiên cứu về phẫu thuật van hai lá khác, đa số các bệnh nhân đều cải thiện lâm sàng sau khi thay van hai lá $[14,15]$.

\section{KẾT LUẬN}

Phẫu thuật thay van hai lá ít xâm lấn qua đường mở ngực phải có nội soi hỗ trợ là phương pháp an toàn, cho kết quả ngắn hạn và trung hạn tốt. Tuy nhiên cần theo dõi dài hơn tại để có kết quả dài hạn của phương pháp.

\section{TÀI LIỆU THAM KHẢO}

1. Glauber, M., et al., Early and long-term outcomes of minimally invasive mitral valve surgery through right minithoracotomy: a 10year experience in 1604 patients. J Cardiothorac Surg, 2015. 10: p. 181.

2. Wu, X., et al., Analysis of the Learning Curve in Mitral Valve Replacement Through the Right Anterolateral Minithoracotomy Approach: A Surgeon's Experience with the First 100 Patients. Heart Lung Circ, 2019. 28(3): p. 471-476.

3. Maganti, M., et al., Predictors of low cardiac output syndrome after isolated mitral valve surgery. J Thorac Cardiovasc Surg, 2010. 140(4): p. 790-6.

4. Cheng, D.C., et al., Minimally invasive versus conventional open mitral valve surgery: a meta-analysis and systematic review. Innovations (Phila), 2011. 6(2): p. 84-103. 
5. Cao, C., et al., A meta-analysis of minimally invasive versus conventional mitral valve repair for patients with degenerative mitral disease. Ann Cardiothorac Surg, 2013. 2(6): p. 693-703.

6. Võ Tuấn Anh and Nguyễn Hoàng Định, Đuờng cong huấn luyện trong phẫu thuật van hai lá it xâm lấn qua đường mở ngực nhỏ bên phải. Tạp chí phẫu thuật tim mạch và lồng ngực Việt Nam, 2019. 26: p. 10-20.

7. Phạm Thành Đạt, Nguyễn Công Hựu, and Lê Ngọc Thành, Thay van hai lá it xâm lấn qua đưòng mở nhỏ ngục phải với nội soi hồ trọ tại trung tâm tim mạch bệnh viện E: Quy trình kỹ thuật và một số kết quả ban đầu. Tạp chí Y học Việt Nam, 2015. 435(10): p. 96-106.

8. Vollroth, M., et al., Conversion rate and contraindications for minimally invasive mitral valve surgery. Ann Cardiothorac Surg, 2013. 2(6): p. 853-4.

9. Grossi, E.A., et al., Minimally invasive versus sternotomy approaches for mitral reconstruction: comparison of intermediate-term results. J Thorac Cardiovasc Surg, 2001. 121(4): p. 708-13.

10. Svensson, L.G., et al., Minimally invasive versus conventional mitral valve surgery: a propensity-matched comparison. J Thorac Cardiovasc Surg, 2010. 139(4): p. 926-32 e1-2.

11. Grossi, E.A., et al., Minimally invasive mitral valve surgery: a 6-year experience with
714 patients. Ann Thorac Surg, 2002. 74(3): p. 660-3; discussion 663-4.

12. Chernov, I., et al., Minithoracotomy vs. Conventional Mitral Valve Surgery for Rheumatic Mitral Valve Stenosis: a Single-Center Analysis of 128 Patients. Braz J Cardiovasc Surg, 2020. 35(2): p. 185-190.

13. Modi, P., et al., Minimally invasive video-assisted mitral valve surgery: a 12-year, 2center experience in 1178 patients. J Thorac Cardiovasc Surg, 2009. 137(6): p. 1481-7.

14. Zhai, J., et al., Minimally invasive mitral valve replacement is a safe and effective surgery for patients with rheumatic valve disease: $A$ retrospective study. Medicine (Baltimore), 2017. 96(24): p. e7193.

15. Liu, J., et al., Mitral valve replacement via minimally invasive totally thoracoscopic surgery versus traditional median sternotomy: a propensity score matched comparative study. Ann Transl Med, 2019. 7(14): p. 341.

16. Mohr, F.W., et al., Minimally invasive port-access mitral valve surgery. $\mathrm{J}$ Thorac Cardiovasc Surg, 1998. 115(3): p. 567-74; discussion 574-6.

17. Phạm Thành Đạt, Nguyễn Công Hựu, and Lê Ngọc Thành, Đánh giá kết quả sớm phâu thuật van hai lá it xâm lấn qua đường mở nhỏ ngục phải có nội soi hố trọ tại trung tâm tim mach bệnh viện E. Tạp chí Y học Việt Nam, 2015. 435(10): p. 107-113. 